\title{
The Relationship Of Service Quality To Client Satisfaction In An Accounting Firm Setting
}

Carl L. Saxby, University of Southern Indiana

Craig R. Ehlen, (Email: CEHLEN@usi.edu), University of Southern Indiana

Timothy R. Koski, Middle Tennessee State University

\begin{abstract}
This paper presents the results of a study using the marketing-based SERVQUAL scale to examine the relationship between service quality and client satisfaction in an accounting firm setting. Using a sample of 154 clients, we confirm that service quality is positively related in clients' satisfaction with their accounting firm. More importantly, we examine the individual dimensions of service quality to provide insight into specific steps accounting firms can take to increase client satisfaction.
\end{abstract}

\section{INTRODUCTION}

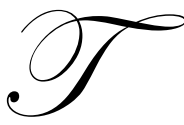

he marketing literature has long been cognizant that service quality can contribute to success among competing service providers. In fact, Hoffman and Bateson (1997, p. 299) suggest that where there are many firms offering nearly identical services within a limited geographic area, "establishing service quality may be the only way of differentiating oneself." Accounting is a service based on rules and regulations that are identical from one business to another, and generally there are many potential accounting firms within a limited geographic area. Thus, providing high levels of service quality - as perceived by clients - is a critical strategic goal for accounting firms.

Measuring service quality is important to accounting firms because higher levels of service quality are associated with higher levels of customer satisfaction. Higher levels of customer satisfaction lead, in turn, to repeat business and ultimately to higher levels of income. Thus, accounting firms should be concerned with maximizing service quality. Accounting firms should be particularly concerned about clients' perceptions of service quality in light of the negative publicity the profession received surrounding Arthur Andersen's role in the collapse of Enron Corporation.

One measure of service quality frequently used in marketing research is the SERVQUAL scale (Parasuraman, Berry, and Zeithaml, 1988). This paper reports the results of a study using the SERVQUAL scale to examine the relationship between service quality and client satisfaction in an accounting firm setting. Consistent with prior research, we find that service quality is positively related to client satisfaction. We then examine the individual components of the SERVQUAL scale to provide insight into what accounting firms can do to improve client satisfaction. A detailed examination of the individual components of the SERVQUAL scale will provide accounting firms with information that will assist them in taking specific steps designed to increase client satisfaction.

\section{LITERATURE REVIEW AND RESEARCH QUESTIONS}

The conceptual model of service quality (Parasuraman, Zeithaml, and Berry, 1985) explains the quality of service received in terms of "gaps." While five potential gaps are identified in the model, only one - the service gap

Readers with comments or questions are encouraged to contact the authors via email. 
- is particularly relevant in the current research. The relevant service gap is any difference between the customers' perceptions of the quality of service actually delivered and their prior service quality expectations. Essentially, early service quality theory held that people form expectations a priori and then compare the perceived actual performance to their prior expectations. When expectations exceed performance - a negative gap - there is dissatisfaction from low perceived service quality. A very close match of expectations to performance produces perceived service quality and satisfaction. A positive gap - performance exceeding expectations - generates customer delight. More recent research has shown that perceived performance alone is an accurate predictor of service quality and satisfaction (Cronin and Taylor, 1992; Teas, 1994).

The SERVQUAL scale (Parasuraman, Berry, and Zeithaml, 1988) measures five dimensions of service quality using two similar 22-item sections that record customers' expectations and perceptions, respectively. The five dimensions of service quality measured by the SERVQUAL scale encompass tangible aspects (service personnel and physical facilities appear neat and professional), reliability factors (ability to meet deadlines and produce error-free results), responsiveness (prompt service, employees willing to help immediately), assurance levels (adequate technical knowledge, secure transactions, inspires confidence), and empathy factors (gives personal attention, operates at convenient hours). Because of concerns regarding the length of the scale and research showing that perceived performance alone is an accurate predictor of quality and satisfaction (Cronin and Taylor, 1992; Teas, 1994), we used an instrument measuring clients' perceptions regarding service quality in the current research. The 22-item SERVQUAL scale used in this research is set forth in Exhibit 1.

\section{Exhibit 1 \\ SERVQUAL Scale}

\begin{tabular}{|l|l|}
\hline $\begin{array}{l}\text { Dimension of } \\
\text { Service Quality }\end{array}$ & Components of Service Quality Dimension - Actual Questions Asked \\
\hline Tangible & $\begin{array}{l}\text { My CPA firm has up-to-date-equipment } \\
\text { My CPA firm's physical facilities are visually appealing. } \\
\text { My CPA firm's employees are well dressed and appear neat. } \\
\text { The appearance of the physical facilities of my CPA firm is in keeping with the type of services } \\
\text { provided. }\end{array}$ \\
\hline Reliability & $\begin{array}{l}\text { When my CPA firm promises to do something by a certain time, it does so. } \\
\text { When I have problems, my CPA firm is sympathetic and reassuring. } \\
\text { My CPA firm is dependable }\end{array}$ \\
& $\begin{array}{l}\text { My CPA firm provides its services at the time it promises to do so. } \\
\text { My CPA firm keeps its records accurately. }\end{array}$ \\
\hline Responsiveness & $\begin{array}{l}\text { My CPA Firm tells its customers exactly when services will be performed. } \\
\text { I receive prompt service from my CPA firm's employees. } \\
\text { Employees of my CPA firm are always willing to help customers. } \\
\text { Employees of my CPA firm respond to customer requests promptly. }\end{array}$ \\
\hline Assurance & $\begin{array}{l}\text { I can trust the employees of my CPA firm. } \\
\text { I can feel safe in my transactions with my CPA firm's employees. } \\
\text { My CPA firm's employees are polite. }\end{array}$ \\
& Employees of my CPA firm have the knowledge to answer my questions. \\
\hline Empathy & $\begin{array}{l}\text { My CPA firm gives me individual attention. } \\
\text { My CPA firm's employees give me personal attention. } \\
\text { My CPA firm's employees know what my needs are. } \\
\text { My CPA firm has my best interests at heart. } \\
\text { My CPA firm has convenient operating hours. }\end{array}$ \\
\hline
\end{tabular}

The SERVQUAL scale has been extensively used in marketing research. Researchers have begun to adapt the SERVQUAL scale to accounting. Freeman and Dart (1993), Bojanic (1991), and Weekes, Scott, and Tidwell (1996) adapted versions of the SERVQUAL scale to accounting and found that all five dimensions of the scale were relevant to client perceptions of service quality. Similarly, Turner, Aldhizer, and Shank (1999) adapted the SERVQUAL scale to study client perceptions of management advisory services (MAS) quality and found that the 
model was a viable method of assessing the quality of MAS provided by CPA firms. Our research addresses client satisfaction with areas of service (audit, consulting, tax, and financial statement preparation) typically provided by CPA firms.

Consistent with previous research, we predict that clients' perception of service quality, as measured by the SERVQUAL scale, is positively associated with client satisfaction. As stated in the null form:

H1: Clients' perception of service quality is positively related to client satisfaction in an accounting firm setting.

More importantly, we undertook an in-depth examination of the individual items comprising the SERVQUAL scale to determine which dimensions of service quality were most important to client satisfaction in an accounting firm setting. Customers generally view reliability as the most important dimension of the SERVQUAL scale (Berry and Parasuraman, 1992). In addition, reliability has consistently been found to be significantly associated with client satisfaction with professional service firms (see e.g., Turner, Aldhizer, and Shank, 1999). Consistent with research in other settings, we predict that accounting firm clients view reliability as the most important dimension of service quality. As stated in the null form:

H2: The reliability dimension of service quality is the most important indicator of client satisfaction in an accounting firm setting.

We then examined those dimensions of service quality found to be most associated with client satisfaction and tested the significance of each item comprising the significant dimensions. Knowing the details of which items in a particular dimension clients perceive as important will assist accounting firms in establishing specific policies designed to improve client satisfaction.

\section{METHODOLOGY}

This research was conducted by mail survey. The survey instrument was developed by the researchers and designed to gather information on customers' perceptions regarding their satisfaction with the quality of service provided by their accounting firm. As discussed earlier, recent research has shown that perceived performance alone is an accurate predictor of service quality and satisfaction (Cronin and Taylor, 1992; Teas, 1994). Therefore, the survey instrument contained 22 questions regarding clients' perceptions of the five dimensions of service quality that comprise the SERVQUAL scale (Parasuraman, Zeithaml and Barry, 1985) (see Exhibit 1). Each of these items was measured on a five-point Likert-type scale.

We also collected information on client satisfaction. Client satisfaction was measured on a five-point Likert-type scale: The following five questions were designed to provide multiple measures of client satisfaction: (1) "In general, I am pretty satisfied with my CPA firm," (2) "Overall, my CPA firm is a good company to do business with," (3) "I want to retain my CPA firm," (4) "Overall, my CPA firm's policies and programs benefit my company," and (5) "Overall, my CPA firm is very fair." The survey instrument also included questions for demographic and classification purposes.

The survey was mailed to all 292 sole proprietorship, partnership, and corporate clients of a large regional accounting firm. (Clients that were either estates or trusts and clients for whom preparing personal federal or state income tax returns was the only professional service rendered were not included in the sample.) The survey was addressed to the primary client contact person for coordinating professional services with the accounting firm. A second request was sent to non-respondents one month after the original survey was mailed. Usable responses were received from 154 clients, a response rate of 53\%. 


\section{SAMPLE CHARACTERISTICS}

The 154 clients included in data analysis are a representative sample of the accounting firm's clients. As shown in Tables 1 and 2, the sample contained a wide range of industries and client sizes.

\begin{tabular}{|lcc|}
\hline \multicolumn{3}{|c|}{$\begin{array}{c}\text { Table 1 } \\
\text { Industry of Participating Clients }\end{array}$} \\
Industry & $\underline{\text { Number }}$ & $\underline{\text { Percent }}$ \\
Manufacturing & 17 & 11.0 \\
Construction & 20 & 13.0 \\
Wholesale/Retail & 46 & 29.9 \\
Not-for-profit & 18 & 11.7 \\
Health care & 9 & 5.8 \\
Other & 42 & 27.3 \\
Missing data & $\underline{1.3}$ \\
Total & $\underline{\underline{154}}$ & $\underline{\underline{100.0}}$ \\
& & \\
\hline
\end{tabular}

\begin{tabular}{|lcc|}
\hline \multicolumn{3}{|c|}{ Table 2 } \\
Size of Participating Clients \\
Annual Revenue & $\underline{\text { Number }}$ & $\underline{\text { Percent }}$ \\
\hline Less than $\$ 500,000$ & 46 & 16.9 \\
$\$ 500,001-\$ 2,000,000$ & 43 & 27.9 \\
$\$ 2,000,001-\$ 10,000,000$ & 55 & 35.7 \\
$\$ 10,000,001-\$ 20,000,000$ & 14 & 9.1 \\
Greater than $\$ 20,000,000$ & 11 & 7.2 \\
Missing data & $\underline{5}$ & $\underline{\underline{154}}$ \\
Total & $\underline{\underline{154}}$ \\
& & \\
\hline
\end{tabular}

Respondents were asked what percent of contact with their accounting firm was related to auditing, consulting, tax services, and financial statement preparation, respectively. As reported in Table 3, respondents used their accounting firm for a wide variety of services.

\begin{tabular}{|c|c|c|}
\hline \multicolumn{3}{|c|}{$\begin{array}{c}\text { Table } 3 \\
\text { Type of Contact with Participating Clients }\end{array}$} \\
\hline Type of Client & Number & Percent \\
\hline Predominantly audit & 28 & 18.2 \\
\hline Predominantly tax & 57 & 37.0 \\
\hline $\begin{array}{l}\text { Predominantly financial } \\
\text { statement preparation }\end{array}$ & 21 & 13.6 \\
\hline Predominantly consulting & 6 & 3.9 \\
\hline Uses several services & 38 & 24.7 \\
\hline Missing data & 4 & 2.6 \\
\hline Total & $\underline{\underline{154}}$ & $\underline{\underline{100.0}}$ \\
\hline
\end{tabular}

Tables 4 through 8 summarize the position, experience, gender, age, and education level of the person within each client firm who answered the survey. Individual respondents held a variety of positions in their firms and had diverse experience and educational backgrounds. In general, however, the individual respondents were experienced professionals who held positions of authority in their company. The wide range of client firms and individual respondents included in the data analysis improves the generalizability of our results.

\begin{tabular}{|lcr|}
\hline \multicolumn{3}{|c|}{ Position of Individual Respondent } \\
Position & $\underline{\text { Number }}$ & $\underline{\text { Percent }}$ \\
\hline Owner/General Manger & 46 & 29.9 \\
President/CEO & 52 & 33.8 \\
Vice-President/CFO & 15 & 9.7 \\
Controller & 19 & 12.3 \\
Accounting Manager & 11 & 7.1 \\
Other & 8 & 5.2 \\
Missing data & $\underline{3}$ & $\underline{\underline{100.0}}$ \\
Total & $\underline{\underline{\mathbf{1 5 4}}}$ & \\
& & \\
\hline
\end{tabular}

\begin{tabular}{|lcr|}
\hline \multicolumn{3}{|c|}{$\begin{array}{c}\text { Table 5 } \\
\text { Experience of Individual Respondent } \\
\text { (Years in Industry) }\end{array}$} \\
Years of Experience & $\underline{\text { Number }}$ & $\underline{\text { Percent }}$ \\
Less than 6 & 15 & 9.7 \\
$6-9$ & 11 & 7.1 \\
$10-15$ & 30 & 19.5 \\
$16-20$ & 25 & 16.2 \\
$21-30$ & 46 & 29.9 \\
More than 30 & 21 & 13.6 \\
Missing data & $\underline{6}$ & $\underline{100.0}$ \\
Total & $\underline{\underline{154}}$ \\
\hline
\end{tabular}




\begin{tabular}{|lcr|}
\hline & Table 6 & \\
Gender of Individual Respondent & \\
$\frac{\text { Gender }}{\text { Female }}$ & $\underline{\text { Number }}$ & $\underline{\text { Percent }}$ \\
Male & 101 & 33.8 \\
Missing data & $\underline{1154}$ & \\
Total & $\underline{100.0}$ \\
& & \\
& & \\
& & \\
\end{tabular}

Table 8

Education Level of Individual Respondent

\begin{tabular}{lcc} 
Education Level & Number & $\underline{\text { Percent }}$ \\
\cline { 2 - 3 } High school graduate & 12 & 7.8 \\
Some college & 43 & 27.9 \\
College graduate & 55 & 35.7 \\
Some postgraduate study & 18 & 11.7 \\
Masters degree or more & 24 & 15.6 \\
Missing data & $\underline{2}$ & $\underline{100.0}$ \\
$\quad$ Total & $\underline{\underline{154}}$ & $\underline{\underline{100.0}}$
\end{tabular}

\begin{tabular}{|lcr|}
\hline \multicolumn{3}{c|}{$\begin{array}{c}\text { Table 7 } \\
\text { Age of Individual Respondent }\end{array}$} \\
$\underline{\text { Age }}$ & $\underline{\text { Number }}$ & $\underline{\text { Percent }}$ \\
Less than 40 & 25 & 16.2 \\
$40-49$ & 61 & 39.6 \\
$50-59$ & 40 & 26.0 \\
60 or more & 21 & 13.6 \\
Missing data & $\underline{7}$ & $\underline{\underline{100.0}}$ \\
Total & $\underline{\underline{154}}$ & \\
& & \\
\hline
\end{tabular}

ANALYSIS OF RESULTS AND DISCUSSION

\section{Reliability Analysis and Factor Analysis}

The five dimensions of the SERVQUAL scale were subjected to both a reliability analysis and a factor analysis. Reliability scores for each dimension exceeded .84 and are reported in Table 9.

All elements of each dimension of service quality loaded on a single factor and explained at least $68.5 \%$ of the variance. Factor analysis results are reported in Table 10.

\begin{tabular}{|lc|}
\hline \multicolumn{2}{|c|}{ Table 9 } \\
Reliability Analysis \\
Dimension of & Reliability \\
Service Quality & Coefficient \\
Tangibles & .8480 \\
Reliability & .8963 \\
Responsiveness & .8449 \\
Assurance & .8852 \\
Empathy & .9128 \\
\hline
\end{tabular}

\begin{tabular}{|lcc|}
\hline \multicolumn{3}{c|}{$\begin{array}{c}\text { Table 10 } \\
\text { Factor Analysis }\end{array}$} \\
Dimension of & Eigenvalues & $\begin{array}{c}\text { Percent of Variance } \\
\text { Explained }\end{array}$ \\
Service Quality & & $68.7 \%$ \\
Tangibles & 2.750 & $71.0 \%$ \\
Reliability & 3.552 & $68.5 \%$ \\
Responsiveness & 2.739 & $74.6 \%$ \\
Assurance & 2.983 & $74.3 \%$ \\
Empathy & 3.717 & \\
\hline
\end{tabular}

\section{Relationship of Service Quality to Satisfaction}

We added the five measures of relationship satisfaction to arrive at an overall satisfaction score. Similarly, we added the individual components of each dimension of service quality (tangibles, reliability, responsiveness, assurance, empathy) to arrive at an overall score for each dimension. The high reliability coefficients and that fact that the individual elements of each dimension of service quality loaded on a single factor made it appropriate to use summated measures of each dimension of service quality in data analysis. The overall scores for each of the five service quality dimensions were then regressed against the overall satisfaction score to test whether service quality is related to client satisfaction. The results are reported in Table 11. Service quality explains $55.4 \%$ of the variation in client satisfaction. This supports Hypothesis One and provides evidence that service quality is positively related to client satisfaction in an accounting firm setting. 
The positive relationship between service quality and client satisfaction did not vary as a function of the either the type of services performed (e.g., audit, tax, financial statement preparation, or consulting) or the personal characteristics (position in the firm, years of experience, gender, age, or education level) of the individual respondents.

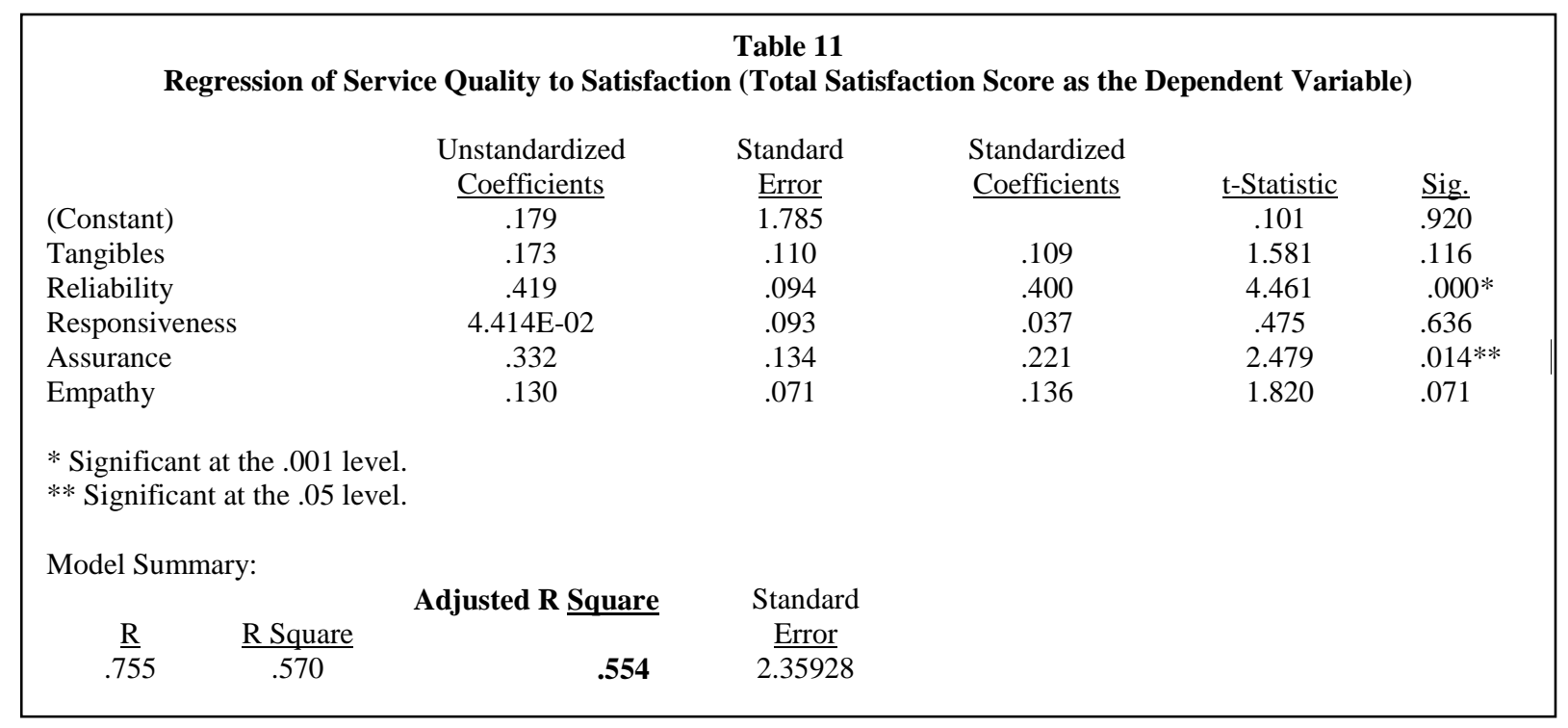

Consistent with Hypothesis Two, the reliability dimension of service quality was significant at the .001 level. The assurance dimension was significant at the .05 level. The tangibles, responsiveness, and empathy dimensions were not significant. These results suggest that accounting firms should concentrate their efforts on the items comprising the reliability and assurance dimensions of service quality. The finding of no results for the tangibles factor is consistent with prior research on professional service firms (Turner, Aldhizer, and Shank, 1988). In fact, some researchers eliminate the tangible component of the SERVQUAL scale when dealing with professional service firms, including accounting firms (see Behn, Carcello, Hermanson, and Hermanson, 1997).

In order to determine whether accounting firms can benefit from concentrating their efforts on particular elements of reliability or assurance, we regressed the individual components of these dimensions on client satisfaction. The regression of the individual components of reliability on client satisfaction is reported in Table 12 .

According to Berry and Parasuraman (1992), reliability is the most important criterion in evaluating service quality. Reliability consists of both the dependability and accuracy components (Berry and Parasuraman, 1992). The item dealing with accuracy (keeps records accurately) is significant, while those dealing with dependability are only marginally significant. It appears that accuracy is of paramount concern to accounting firm clients. Timeliness (provides services at times promised), on the other hand, is not. Accounting firms should strive to perform work accurately, even if it's at the expense of timeliness.

Assurance is the other dimension of service quality that was significant. The regression of the four individual components of assurance on client satisfaction is reported in Table 13.

The only individual component in the assurance dimension of service quality that was significant was whether the accounting firm has the knowledge necessary to answer questions. Components dealing with trust and politeness were not significant. The results on the trustworthy component, however, may have to be reexamined in light of the crisis in public confidence created by Arthur Andersen's role in the Enron scandal. 


\begin{tabular}{|c|c|c|c|c|c|}
\hline \multicolumn{6}{|c|}{$\begin{array}{l}\text { Table } 12 \\
\text { Analysis of Reliability Components of Service Quality }\end{array}$} \\
\hline & $\begin{array}{l}\text { Unstandardized } \\
\text { Coefficients }\end{array}$ & $\begin{array}{l}\text { Standard } \\
\text { Error }\end{array}$ & $\begin{array}{l}\text { Standardized } \\
\text { Coefficients }\end{array}$ & $\underline{\mathrm{t}-\text { Statistic }}$ & $\underline{\text { Sig. }}$ \\
\hline (Constant) & 5.831 & $\overline{1.346}$ & & 4.331 & .000 \\
\hline Keeps Promises & .893 & .520 & .226 & 1.718 & .088 \\
\hline Sympathetic and reassuring & .889 & .326 & .204 & 2.725 & $.007 *$ \\
\hline Dependable & .911 & .521 & .185 & 1.748 & .083 \\
\hline $\begin{array}{l}\text { Provides services at times } \\
\text { promised }\end{array}$ & $-3.619 \mathrm{E}-02$ & .559 & -.008 & -.065 & .948 \\
\hline \multicolumn{6}{|l|}{ * Significant at the .01 level. } \\
\hline \multicolumn{6}{|l|}{ Model Summary: } \\
\hline$\frac{\mathrm{R}}{.711} \quad \frac{\mathrm{R} \text { Square }}{.505}$ & $\begin{array}{l}\text { Adjusted } \\
\mathrm{R} \mathrm{Square} \\
.488\end{array}$ & $\begin{array}{l}\text { Standard } \\
\text { Error } \\
2.5508\end{array}$ & & & \\
\hline
\end{tabular}

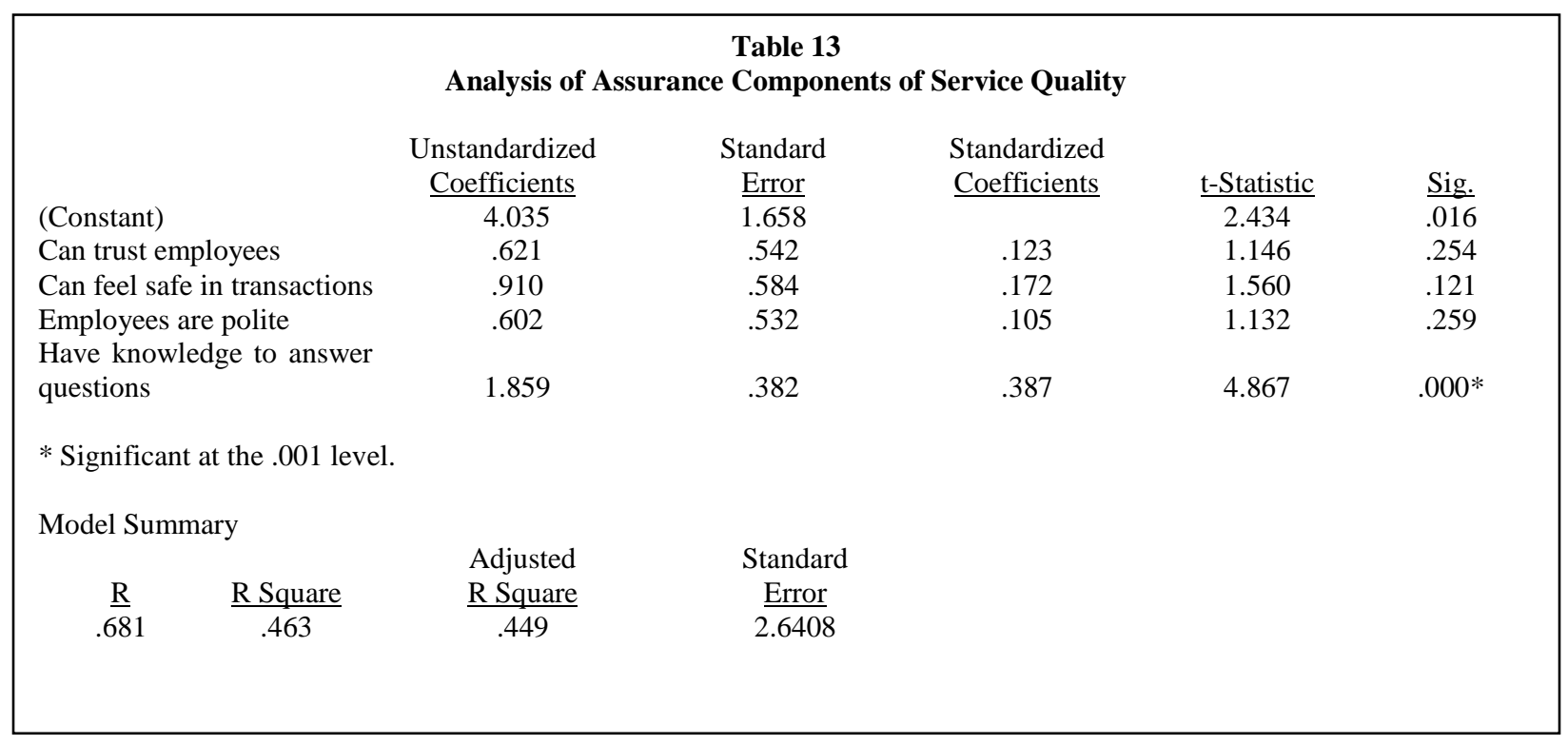

The significant result for the knowledge portion of the assurance dimension of service quality illustrates the importance of proper employee training and lifelong learning. Clients demand that their accounting firms be knowledgeable of an ever-changing array of rules and regulations. This finding illustrates the importance of continuing professional education to CPA firms and their employees.

In conclusion, accounting firms can increase client satisfaction by concentrating on items that traditionally set certified public accountants apart from other professional firms - reliability and assurance. Accounting firms should strive to be as current as possible on accounting regulations and make sure their clients are aware of their level of knowledge. Providing clients with accurate answers is an important component of client satisfaction. Accounting firms should stress continuing education to ensure they provide clients with accurate, up-to-date advice. 
Finally, accounting firms should take steps designed to ensure that their employees are sympathetic and reassuring to clients.

\section{REFERENCES}

1. Behn, B., J. Carcello, D. Hermanson, and R. Hermanson. 1997. The determinants of audit client satisfaction among clients of Big Six firms. Accounting Horizons, (March): 7-24.

2. Berry, L., and A. Parasuraman. 1992. Marketing Services: Competing Through Quality, New York: The Free Press.

3. Bojanic, D.1991. Quality Measurement in Professional Service Firms. Journal of Professional Services Marketing, 7, 2: 27-36.

4. Cronin, J., Jr., and S. Taylor. 1992. Measuring service quality: A reexamination and extension. Journal of Marketing, 56, 3: 55-68.

5. Freeman, D., and J. Dart. 1993. Measuring the perceived quality of professional business services. Journal of Professional Marketing Services, 9, 1: 27-47.

6. Hoffman, D., and J. Bateson. 1997. Essentials of Service Marketing. Fort Worth, TX: The Dryden Press.

7. Parasuraman, A., L. Berry, and V. Zeithaml. 1998. SERVQUAL: A multiple-item scale for measuring customer perceptions of service quality. Journal of Retailing, 64, 1: 12-40.

8. Parasuraman, A., V. Zeithaml, and L. Berry. 1985. A conceptual model of service quality and its implications for future research. Journal of Marketing, 49, 4: 41-50.

9. Teas, R. 1994. Expectations as a comparison standard in measuring service quality: An assessment of a reassessment. Journal of Marketing, 58, 1: 132-139.

10. Turner, L., G. Aldhizer III, and M. Shank. 1999. Client perceptions of MAS quality as measured by a marketing-based service quality model. Accounting Horizons, 13, 1: 17-36.

11. Weekes, D., M. Scott, and P. Tidwell. 1996. Measuring quality and client satisfaction in professional business services. Journal of Professional Services Marketing, 14, 2: 25-37. 